\title{
Determinants of Unemployment in Namibia
}

\author{
Joel Hinaunye Eita (Corresponding author) \\ School of Business and Economics, Monash University (South African Campus) \\ P/B X60, Roodepoort, 1725, South Africa
}

Tel: 2711-9504-054 E-mail: hinaeita@yahoo.co.uk or joel.eita@buseco.monash.edu

Johannes M. Ashipala

United Nations Development Programme (UNDP) Namibia, Private Bag 13329, Windhoek, Namibia

E-mail: johannes.ashipala@undp.org

The research is financed by United Nations Development Programme - Namibia

\begin{abstract}
This study investigates the causes of unemployment in Namibia for the period 1971 to 2007. The analysis is carried out through an extensive review of the relevant literature, microeconomic and macroeconomic models of unemployment. The unemployment model (with macroeconomic variables) is estimated using the Engle-Granger two-step econometric procedure. The results revealed that there is a negative relationship between unemployment and inflation in Namibia. Unemployment responds positively if actual output is below potential output, and if wages increase. An increase in investment causes unemployment to decrease significantly. The results provide evidence that the Phillips curve holds for Namibia and unemployment can be reduced by increasing aggregate demand. It is important to increase output up to the country's potential, and there is a need for wage flexibility (workers need to reduce their wage demands) in order to decrease unemployment in Namibia. Increasing investment will reduce unemployment significantly.
\end{abstract}

Keywords: Unemployment, Cointegration, Unit root, Output gap, Investment, Namibia

\section{Introduction}

Namibia has enjoyed about 20 years of peace and stability. However, the rise in unemployment rate in Namibia has the potential to cause serious threat to the prevailing peace and stability in the country. In general, unemployment has a significant impact on poverty, homelessness and affects family cohesion. It causes hopelessness and other social evils such as crime, violence, break up of families, alcoholism and prostitution. The 2004 Labour Force Survey of Namibia indicates that that unemployment in Namibia is high even by developing country's standard. The narrow definition of unemployment which includes only people who are unemployed and still looking for jobs is at 21.9 percent. The broad definition of unemployment which includes also the people who are unemployed and not looking for jobs puts unemployment rate at 36.7 percent. Unemployment rate for women is higher than the one for men, but the youth (mainly school leavers) are the most affected. Youth unemployment (youth in Namibia is defined as people between the age of 15 and 30) is most socio-economic problem and has the potential to cause social discontent. Before Namibia's independence in 1990, black people (mainly youth) had no real expectation of being able to live a good life. This has been changed after independence and led to people to believe that they can get jobs and have a good life, but the economy is not generating enough job opportunities.

Namibia has achieved macroeconomic stability after independence, but this was not sufficient to reduce unemployment. The economy grew by 4.6 percent between 2000 and 2005 and inflation of a single digit was achieved during the same period. The government has also pursued prudent fiscal policy, maintained well-developed infrastructure and strong legal and regulatory environment. Despite these achievements, unemployment rate continued to rise. This suggests that achieving macroeconomic stability is not sufficient to create the much-needed jobs and reduce unemployment. Statistics from the various issues of the Labour force indicate that employment grew by less than or one percent per year during the period 1992 to 2004. This is in contrast to the annual growth of the labour force of 3 percent during the same period. This resulted in an increase in unemployment rate (narrowly defined) from 19 percent in 1992 to 21.9 percent in 2004. The low growth in 
jobs created has resulted in rising unemployment. Although the unemployment rate in Namibia is comparable to other SACU (Southern African Customs Union) member countries such as South Africa and Lesotho, it is above a number of African peers. Using the narrow definition of unemployment in Namibia is higher than in other African countries (such as Botswana, Tunisia, Egypt, Mauritius and Cameroon) as shown in Table 1.

Gaomab II (2007) suggested that the 2004 statistics on unemployment in Namibia should be interpreted with caution because the Namibia Household Income and Expenditure Survey of 2004 found that Namibians were better off than they were in 1994 and that Namibia was on track to meet the United Nations' Millennium Development Goals by 2015. This Survey also found that the proportion of households living in severe poverty declined from 8.7 percent to 3.9 percent and the Gini coefficient declined from 0.7 to 0.6 . These findings contradict the Labour Force Survey of 2004 and therefore paradoxical. There is general consensus that increase in unemployment is positively related to increase in poverty. This contradiction should be taken into account when analysing unemployment statistics in Namibia.

The National Development Plans which are the implementing medium-term plans for the national long-term goal Vision 2030 are clear on the issue of unemployment. The government policy is aimed at promotion of growth, increasing employment and alleviate poverty, as well as reduction of unequal distribution of income. The key instruments for achieving these objectives are high investment in education, health, pension system and other social services. Measures have also been taken by the government to create employment and address labour market inequalities. Namibia follows a market-oriented and open economic policy because it acknowledges that unemployment and poverty can be reduced by achieving high economic growth. Under such a situation of high economic growth, it could be expected that employment will increase, but this has not been the case. Unemployment continued to increase. This raise an interesting question on what are factors determining unemployment in Namibia.

In light of the above, the objective of this study is to investigate the determinants of unemployment in Namibia. The study paints a picture of the distribution of unemployment in Namibia. The investigation is conducted through a review of relevant literature, microeconomic and macroeconomic models of unemployment. It uses an econometric model to determine macroeconomic factors which drive unemployment in Namibia. The rest of the study is organised as follows. Section 2 discusses the features of the unemployed in Namibia. Section 3 reviews the literature on the determinants of unemployment in Namibia. Section 4 presents the model for Namibia. Section 5 discusses the data and estimation technique, while Section 6 presents the results. Section 7 concludes.

\section{Features of the unemployed in Namibia}

Unemployment is defined according to international statistical definition as people who are without work, available to work and actively seeking for work. This is called a strict or narrow definition of unemployment. This narrow definition excludes many unemployed people who are without a job and are available to work but not actively looking for employment from the labour force.

According to Odada (2008) the international statistical standards adopted in 1982 introduced a provision which allowed the narrow definition of unemployment to be dropped in situations where the conventional means of seeking work are of limited relevance where the labour market is largely unorganised, labour absorption at the time is inadequate or where most people are self-employed. The broad definition of unemployment is recommended because it includes all people without a job, who are available to work even if they are not actively looking for employment. The broad definition always results in high unemployment than the strict or narrow definition of unemployment.

The broad definition of unemployment is supported by labour market conditions in Namibia. Odada (2008) argues there are limited conventional means of looking for jobs because the majority of Namibians live in the rural areas. Since the majority of the population lives in the rural areas, they have limited access to print and electronic media. The types of jobs that can be done by the majority of people in the rural areas are not advertised in the media. Generally, there is no market place in the rural areas (where majority of the population live) of Namibia where people who are looking for jobs and employers can meet. This resulted in a situation in the rural areas where people who are unemployed and are available to work, but are not actively looking for work because they do not know where to look for work. There is also a problem of underemployment in Namibia such that people who consider themselves employed have low productivity and it is not easy to distinguish them from those that are unemployed. Table 2 and Table 3 present the labour force, employment and unemployment for the $1991-2004$ using the strict and broad definitions of unemployment.

The two definitions of unemployment yield different rates of unemployment. Table 2 which shows that when using the narrow definition of unemployment, the 1991 NPHC, 1993/1994 NHIES, 1997 NLFS, 2000, NLFS 
and the 2004 NLFS produced unemployment rates 19.1, 19.4, 19.5, 20.2 and 21.9 percents. Table 2 shows that the total number of people employed decreased from 388014 in 1991 to 350280 in 1994. It then increased to 401203 in 1997 and 431849 in 2000 before decreasing to 385329 in 2004. Odada (2008) attributes the decrease in the number of people employed between 1991 and 1994 to the emigration of people who thought that South Africa was a better place to live after Namibia gained political independence in 1990. These people maintained close links with their families in South Africa. South Africa was transformed to democracy in 1994, and some people who migrated to South Africa came back to Namibia. Hence the big fluctuations in the number of people employed between 1991 and 1997 (Odada, 2008, p. 53). The increase in unemployment in 2004 suggests that there are some factors in Namibia which makes the economy unable to absorb a large number of the unemployed people. This could be attributed to the fact that Namibia has small manufacturing base, and this makes the economy unable to absorb the majority of the unemployed people. The next sections review both microeconomic and macroeconomic determinants of unemployment.

\section{Literature Review on Determinants of Unemployment}

There are various studies that investigated the determinants of unemployment. Some studies analysed the determinants of unemployment from a microeconomic perspective, while others investigated the macroeconomic determinants of unemployment in both developed and developing countries. There are also different theoretical models that are relevant for the investigation of the determinants of unemployment. Monternsen (1970) and Lippman and McCall (1976) presented a commonly chosen framework job search model. This model states that when people become unemployed, the expected duration of their unemployment depends on probability of receiving job offers and accepting the offers. The job offer is determined by factors such as education, skill, experience and local demand condition, all which make a specific person attractive to employers. This model assumes that the probability that an individual accept offer of employment depends on the individual's minimum acceptable wage. The minimum acceptable wage is called reservation wage and is determined by cost of looking for a job, unemployment income, expected distribution of wage offers and probability of receiving subsequent job offers.

Foley (1997) used information contained in a nationally representative longitudinal survey to analyse unemployment duration in Russia during the early years of transition. The analysis was done by using a competing-risks, discrete-time waiting model augmented to incorporate unobserved heterogeneity. This was done to analyse whether the role of demographic characteristics, alternative income support and local demand conditions in explaining unemployment. The results indicate that married women are found to experience significantly longer unemployment compared to their male counterpart. Older individuals expect to be unemployed longer than younger individuals. Highly skilled or educated individuals have very low unemployment rate compared to those without education or low skilled individuals.

Kingdon and Knight (2001) studied the unemployment in South Africa using the probit model. The study was conducted using two national household surveys for the mid-1990s. The results indicate that unemployment in South Africa is determined by among others, race, education, age, gender, home ownership, location. Bhorat (2007) analysed a number of labour economic and social choice theories and identified factors or common variables that determine the chance of somebody to be employed or not. A number of variables from economic and social theories that determine unemployment are (Bhorat, 2007):

- Economic theory states that more education results in a greater likelihood of employment. In many middle and low income countries there is shortage of highly educated individual and this result in high unemployment. Although there is a scarcity of highly-educated people many African countries (including Namibia), Egypt has surplus of highly-educated people who find it difficult to get jobs. Despite that, there has been a shift away from unskilled/semi-skilled labour towards more skilled labour in low and middle income countries.

- Employment is affected by choices in how to utilise hours in the day. This is related to household responsibilities such as fetching water, wood, childcare, care of the elderly and leisure activities.

- Gender and culture have an impact on employment. Women are often more likely to be home-makers dependent on the male of the household. This depends significantly on who is the head of the household or family. The head of the household is often the one who is working and more likely to be the breadwinner. The issue of race also play a role in many developed and developing countries.

- In standard neo-classical labour theory, it is argued that high unemployment rate is caused by high wage. This means that if there is involuntary unemployment, the real wage will fall and unemployed people will find a job at a lower wage. The decrease in real wage implies lower costs to employers and it encourages them to employ more workers. 
- The composition of the household determines unemployment. A household that has many teenagers and babies can have impact on the likelihood of employment by acting as an incentive to find employment.

- There is a correlation between marital status and employment in both developed and developing countries. It is argued that once a person is married, there is economic and psychological incentive to find employment. Generally, it is viewed that married men are less risky employees because they have settled down. However, this is highly debatable because someone may be employed in the first place and this attracts potential partners to him/her. There is a need to know what happened in the first place.

- Another factor explaining unemployment is wealth of the family or household. People from poor families have little or no money to actively look for jobs and this causes geographical immobility to areas where jobs are located.

There are also studies which investigates the macroeconomic determinants of unemployment. Valadkhani (2003) investigated the causes of unemployment in Iran. The study specified an equation for the unemployment rate in Iran. The equation was specified as follows:

$$
\begin{aligned}
\ln U N_{t} & =\alpha_{0}+\alpha_{1} \Delta \ln P_{t}+\alpha_{2}\left[\ln Y_{t}^{a}-\ln Y_{t}^{p}\right]+\alpha_{3} \ln U N C E R_{t}+\alpha_{4} \ln \Delta I_{t}, \\
& +\alpha_{5} \ln U N_{t-1}+\alpha_{6} \ln D+\varepsilon_{t}
\end{aligned}
$$

where $U N$ is unemployment rate, $P$ denotes consumer price index, $\ln Y^{a}-\ln Y^{p}$ is a measure of output gap ( $Y^{a}$ and $Y^{p}$ are actual and potential output), UNCER is a proxy for economic uncertainty, $I$ is the total investment $D$ represents dummy variables and $\varepsilon$ is the residual or error term. The error term or residual represents other variables that can influence unemployment but are not included in the model.

Theoretical justification and sign expectations of the variables in Equation (1) are as follows. The consumer price index is included in the equation because there is theoretical relationship between inflation and unemployment rate. The hypothesis is that there is a trade-off between unemployment and inflation (Phillips curve). The coefficient of the consumer price index is expected to be negative if the Phillips curve hypothesis holds. If it does not hold, the coefficient will be positive and this is referred to as stagflation. Stagflation is a situation where unemployment and inflation are moving in the same direction. If the Phillips curve holds it means that an increase in inflation causes unemployment to decrease and vice versa. On the other hand, if the Phillips curve does not hold, it suggests that an increase in inflation results in higher unemployment and this is a stagflation situation.

As Fahrer and Pease (1993) and Valadkhani (2005) stated, a measure of output gap is included in the equation, where unemployment is specified as a function of the gap between actual and potential output. It is expected that if actual output become less than the potential output, unemployment should increase and this means that $\alpha_{2}>0$. The coefficient of output gap is expected to be positive indicating that an increase in this variable results in higher unemployment.

A measure of uncertainty is included in the unemployment equation because the economic environment can be volatile and adversely affects unemployment. Measuring economic uncertainty is not easy, and Valadkhani (2003) used the difference between the black market exchange rate and the official exchange rate or black market premium as a measure of uncertainty. It is expected that an increase in economic uncertainty causes unemployment to rise. This means that a positive relationship or $\alpha_{3}>0$ is expected.

The growth in total investment is included in the equation as one of the main determinants of unemployment. It is expected that an increase in investment can cause a decrease in unemployment rate since unemployment is structural. As Valadkhani states, a positive growth in real investment can reduce unemployment, and that means $\alpha_{4}<0$. Adaptive expectation is added to the unemployment equation by including the lagged value of the unemployment rate.

Valadkhani estimated Equation (1) for the period 1968 to 2000 by using the general to specific econometric technique and a simultaneous equation to examine the major determinants of unemployment in Iran. The results revealed that there exists a trade-off between inflation and unemployment, although persistent and soaring inflation can lead to currency depreciation which worsens unemployment. If actual output is less than the potential output, unemployment will increase. Increase in investment reduces unemployment, while increase in economic uncertainty cause unemployment to increase. 
Wakeford (2004) investigated the relationship between average real wages, productivity and employment in South Africa's manufacturing sector. Since South Africa has a large number of unemployed workers, observed employment may be taken to reflect the demand for labour rather than the supply of labour. The demand for workers, within the neoclassical framework is typically derived from a production function. It depends on factor prices (negatively on wages and positively on the cost of capital). It also depends positively on output. Wakeford substituted labour productivity instead of output. The impact of labour productivity on output can be positive or negative. An increase in productivity can reduce the demand for workers, as the existing labour is more efficient. A rise in productivity could impact positively on the employment through an output effect which increase demand for labour.

Monastiriotis (2006) explored the macroeconomic determinants of UK regional unemployment. The study draws on the Keynesian and monetarist explanations of unemployment. It also elaborates on how the two main theoretical approaches perceive the role of price, capital accumulation, macroeconomic shocks and labour market rigidities in the determination of unemployment. In the Keynesian approach, the relationship between unemployment and its determinants is specified as follows:

$$
U_{t}=\gamma_{0}+\gamma_{1} U_{t-1}+\gamma_{2} \Delta K_{t}+\mu_{t},
$$

where $U_{t}, \Delta K_{t}, \mu_{t}$ are unemployment, rate of capital growth (accumulation), and error term. Equation (2) states that the level of unemployment depends on past unemployment, and the rate of capital growth. Monastiriotis argued that although the specification in Equation (2) does not allow for the role of labour market rigidities in determining unemployment, a possible relation between the two variables can be provided by assuming that rigidities influence the impact that capital growth has on unemployment. It is assumed that if the labour market is more rigid, capital growth will have a stronger impact on unemployment reduction. If the labour market is flexible, the response of unemployment to change in capital accumulation will be little. This has the following implication:

$$
U_{t}=\varphi_{0}+\varphi_{1} U_{t-1}+\varphi_{21} \Delta K_{t}+\varphi_{22}\left(\Delta K_{t} F_{t}\right)+\varepsilon_{t}
$$

As Monastiriotis stated, $\gamma_{2}=\varphi_{21}+\varphi_{22} F_{t}$ and $F_{t}$ is a measure of labour market flexibility. Equation (3) states that $\varphi_{21}<0$ and $\varphi_{22}>0$, which reflects the assumption that capital growth decreases unemployment, but by little when the labour market is flexible.

According to the monetarist model, the rate of capital growth does not play role in unemployment determination. According to Monastiriotis, the actual unemployment depends on the structural rate of unemployment, $U^{*}$, cyclical factors and shocks that are exogenous. Unemployment can be formally expressed as a function of rigidities in the labour market. The cyclical factors influences and macroeconomic shocks are approximated with change in inflation rate $((\triangle I N F)$ and productivity growth rate $(\triangle P R O D)$. The monetarist model can formally be presented as:

$$
U_{t}=\phi_{0}+\phi_{1} U_{t-1}+\phi_{2} \Delta I N F+\phi_{3} \Delta P R O D+\phi_{4} F_{t}+\mu_{t}
$$

where $\mu_{t}$ is the error term. Equation (4) highlights the impact of the interaction between macroeconomic shocks and labour market institutions on unemployment and unemployment persistence. Further details on the Keynesian and monetarist models or approaches to unemployment are presented in Monastiriotis (2006: 13-18). In an attempt to understand South Africa's economic puzzles, Rodrick (2006) explained the cause of unemployment in South Africa. According to Rodrick, high unemployment resulted from the shrinkage of the non-mineral tradable sector since the early 1990s. The weaknesses of the export-oriented manufacturing deprived South Africa, the growth opportunities and resulted in an increase in unemployment. Non-mineral tradables especially manufacturing are the key for growth and employment in South Africa. Export-oriented strategy that increase the relative profitability of producing tradables for world markets will create economic growth by pulling labour into productive activities where their marginal products is very higher. Tradables are low skill intensive in South Africa and could help the country to generate employment.

Another study on the determinants of unemployment in South Africa was conducted by Schoeman et al. (2008). This study estimated unemployment as a function of total fixed capital stock, unionisation as percent of formal employment, real effective exchange rate, crude oil price and bankers' acceptance rate. Specifically, the equation was specified as follows: 


$$
U=f(K, U N I O N, R E E R, C R U D E, B A)
$$

Where $U, K, U N I O N, R E E R, C R U D E, B A$ are unemployment rate, total fixed capital stock, unionisation as percentage of formal employment, real effective exchange rate, crude oil price and bankers' acceptance rate. The results revealed that increase in capital causes reduction in unemployment and this is associated with the theory that increased investment creates jobs. Increased unionisation and crude oil price, appreciation of the real exchange, and strict monetary policy lead to a rise in unemployment rate.

\section{The Model for Namibia}

Following a review of the literature in Section 3, this study considers macroeconomic model (model with macroeconomic variables) for estimating unemployment in Namibia. Microeconomic models are not applied in this study because of data limitations. It applies the Valadkhani (2003) model to Namibia. Many macroeconomic studies estimated the employment equation instead of unemployment equation. The advantage of the Valadkhani model is that it estimates unemployment equation instead of the employment equation as done by some studies. The data for variables used in the Valadkhani model are available in Namibia. The model is slightly adjusted to fit the Namibian situation. It will be estimated as follows:

$$
\ln U_{t}=\alpha_{0}+\alpha_{1} \ln P_{t}+\alpha_{2}\left[\ln Y_{t}^{a}-\ln Y_{t}^{p}\right]+\alpha_{3} \ln R W_{t}+\alpha_{4} \ln I_{t}+\alpha_{5} \ln P R O D_{t}+\varepsilon_{t}
$$

where $R W$ and $P R O D$ are real wages and productivity. All other variables are as defined before. Since various issues of Namibia Labour Force Survey indicated that more than 80 percent of the unemployed people have very low education, it would be appropriate to include a variable that represents education. That variable is not included in this model because of lack of data for all variables that can be used as proxy for education. This study acknowledges that unionisation of workers is an important variable, but it is not included in the model because of data unavailability.

\section{Data and Estimation Technique}

\subsection{Data sources and Variable Definition}

The study uses annual data and estimation covers the period 1971 to 2007. The data are sourced from Cornwell et al. (1991), the National Planning Commission (1999; 2006; 2008), Hartmann (1988), Bank of Namibia (1991; 2004; 2006; 2007) and Ministry of Labour and Social Welfare (1997; 2000; 2004). Unemployment is defined as the difference between the total labour force and total employment. Unemployment rate is then taken as the total unemployment as percent of the total labour force. Prices are proxied by the consumer price index at 1995 base year.

Potential output is computed by using the Hodrick and Prescott (1997) filter (also called HP filter). The HP filter is widely used in the literature to decompose data into a trend and a cycle. It is a mathematical tool used in macroeconomics, mainly in the theory of real cycle. It is used to get a smoothed non-linear representation of the data or series (one which is more sensitive to long-term than to fluctuations in the short-term). A multiplier $\lambda$ is modified to achieve adjustment of the sensitivity of the trend to short-term fluctuations. It is also widely used to calculate potential output from actual output. The HP filter estimates $Y^{p}$ from $Y^{a}$ by minimising the variance of $Y^{a}$ around $Y^{p}$. As Valadkhani (2003) states, the HP filter sets the potential output with the aim of minimising the loss function as follows:

$$
L=\sum_{t=1}^{T}\left(Y_{t}^{a}-Y_{t}^{p}\right)^{2}+\lambda \sum_{t=2}^{T-1}\left[\left(Y_{t+1}^{p}+Y_{t}^{p}\right)-\left(Y_{t}^{p}-Y_{t-1}^{p}\right]^{2}\right.
$$

Where $\lambda$ is a smoothing weight on potential output and $T$ is the size of the sample. Hodrick and Presccott (1997) suggest that the smoothing weight should be 100 for annual data. Therefore in this study, the smoothing weight is 100. The potential output is computed using three measures of output. These are total real GDP, real GDP of the secondary sector (the secondary sector in Namibia includes manufacturing, electricity and water, and construction) and real manufacturing GDP.

Real wage is computed as remuneration or compensation of employees deflated by the consumer price index. Gross domestic fixed capital formation is taken as measure of investment, while productivity is computed as real GDP divided by the total employment. Uncertainty is measured as the difference between equilibrium exchange rate and actual exchange rate with respect to the US\$. The HP filter was used to compute the equilibrium exchange rate. 


\subsection{Estimation Technique}

The availability of data determines the appropriate econometric technique to be used. The number of methods that would be feasible is limited because this study uses a limited data set or few observations. Since most economic variables are nonstationary (they contain unit roots), the study uses cointegration methodology to analyse the data. When variables are nonstationary, traditional Ordinary Least Squares (OLS) estimation method is not sufficient and causes spurious regression results. Spurious regression presents results that are nonsensical.

Despite its potential defects, the Engle-Granger two steps estimation technique is applied in this study. This technique involves the determination of long-run cointegration relationship by testing for stationarity of the residuals from the long-run equation. Stationarity of the residuals is tested using the Augmented Dickey-Fuller (ADF) test statistic. Rejection of the null of nonstationarity (unit root) means that the variables in the equation are cointegrated. If there is any nonstationarity, it will be corrected for by means of a short-term error correction model (ECM). This study acknowledges that the Engle-Granger two step estimation technique has potential weaknesses. It assumes that there is one cointegrating vector. The other weakness is that if there is an error in the first step, it will be carried over to the second step of the estimation.

This study is aware that there are other estimation techniques that are better or more powerful than the Engle-Granger two step technique. Multivariate cointegration techniques such as Johansen's full information maximum likelihood are more powerful than the Engle-Granger two step technique. However, these techniques require more data (many observations). It is important to mention that the ADF test statistic has potential defects. This test has low power and tend to under-reject the null of unit root. There are other tests for unit roots that are more powerful than ADF test statistic. These tests are Kwiatkowski-Phillips-Schmidt-Shin (KPSS) and Ng-Perron (NP). KPSS and NP test statistics also require more data. It is for these reason that this study applies the Engle-Granger two step estimation technique and ADF test statistic.

\section{Empirical Results}

\subsection{Unit Root Test Results}

Unit root test is the first step in the estimation. It involves univariate characteristics of the variables used in the estimated equation. The variables are tested for stationarity using the ADF test statistic. The results are presented in Table 4. Table 4 indicates that most variables contain a unit root (except measures output gap and productivity) or they are nonstationary in levels. They are I(1) because they become stationary after first differences. Consumer price index is nonstationary even in first difference form. The consumer price index variable is I(2) because it become stationary when differenced twice.

\subsection{Estimation Results}

Table 5 presents the long-run or cointegration estimation results of three variations of Equation (6). The second column presents the results when GDP gap is computed using total GDP. The results column 3 uses GDP gap generated from the GDP of the secondary sector. The last column uses GDP gap computed from manufacturing GDP. The results in both column 2, 3 and 4 show that an increase in prices causes unemployment to decrease. However the results in the second and fourth column show that the coefficient is not statistically significant. Column 2 indicates that there is a significant negative relationship between inflation and unemployment. A one percent increase in inflation causes unemployment to decrease by 0.2 percent. This provides evidence that the the Phillips curve hypothesis holds for Namibia. There is a negative relationship between inflation and unemployment in Namibia. If there is an increase in the inflation rate unemployment will decrease.

The coefficient of the output gap is positive in both columns (2,3 and 4) and statistically significant when total GDP and secondary sector's GDP are used to compute output gap. However, when manufacturing GDP is used the coefficient becomes statistically insignificant although it has the expected sign. The statistical insignificance of GDP gap computed using manufacturing GDP could be explained by the fact that labour markers in this sector in Namibia are not flexible. This can also be attributed to the fact that the data used in the estimation are obtained from different sources. The results indicate that if actual output is less than potential output, unemployment will increase. Column 2 and 3 indicate that and increase in output gap by one percent causes unemployment to increase by 1.3 and 0.8 percent.

All estimated models shows that increase in wages are associated with an increase in unemployment. A one percent increase in wages causes unemployment to increase by $0.9,1.8$ and 1.6 percent. The coefficients are all statistically significant. This means that an increase in the cost of labour is associated with an increase in unemployment. The results are in line with those obtained by other studies such as Eita and Du Toit (2009). 
Increase in investment causes unemployment to decrease. A one percent increase in investment results in unemployment to decrease by $0.4,0.2$ and 0.4 percent. All the coefficients are statistically significant. This suggests that unemployment in Namibia can be reduced by increasing investment. Other variables such as productivity and time trend were included in the estimation but their coefficients are not statistically significant. These results are fairly comparable to that of Valadkhani (2003) and Schoeman et al. (2008). The results suggest that unemployment in Namibia can be reduced by increasing investment.

The residuals from the regressions presented in Table 5 were tested for stationarity using the ADF statistics and the results revealed that the null hypothesis of no cointegration is rejected. This means that there is cointegration between unemployment and the explanatory variables. Since the variables are cointegrated for both models, the next step is to estimate the ECM. The results of the ECM are presented in Table 6.

The dummy variable for Namibia's independence in 1990 (DUMIND) is included in the ECM (column 4) to fully explain the short-run dynamics of the unemployment function. The results in Table 6 indicate the explanatory variables are statistically significant. The coefficients of the ECM for both models are negative and statistically significant. This is an indication that the dynamics adjust towards equilibrium instead of moving away from it. Columns 2, 3 and 4 indicate 35, 50 and 48 percent of disequilibrium are corrected every year. The diagnostic tests were performed on the error correction model and the results showed that the equations are well-specified and did not violate the Gaussian assumptions or classical linear regression assumptions. The $\mathrm{R}$-squared of more than 50 percent shows that the regressions are good fit. More than 50 percent of the variations in the dependent variable are explained by the explanatory variables.

\section{Conclusion and Policy Implications}

This study analysed and investigated the determinants of unemployment in Namibia. The analysis and investigations are conducted through a review of the relevant literature and models. Various microeconomic and macroeconomic models were reviewed. The microeconomic models were not applied because of data unavailability. The study has chosen a macroeconomic model to investigate factors that influence unemployment in Namibia. The Valadkhani (2003) model was estimated for Namibia. The Engle-Granger two step procedure was used to estimate the model for Namibia. The estimation covered the period 1971 to 2007. The results indicated that there is evidence of negative relationship between unemployment and inflation. This gives evidence that the Phillips curve holds for Namibia. This shows that unemployment in Namibia can be reduced by stimulating spending (which cause high inflation).

If actual GDP is below potential GDP, there will be an increase in unemployment. The output gap was computed using three measures of GDP (total GDP, secondary sector's GDP and manufacturing GDP). The results show that when total GDP and GDP of the secondary sector are used as measures of output gap, the coefficients are positive and statistically significant. However, when manufacturing GDP is used as a measure of output the coefficient positive but statistically insignificant. This means that although output of the manufacturing sector reduces unemployment, the effect is not significant. This is unexpected because it is generally accepted an increase in manufacturing GDP will generate more jobs and reduce unemployment significantly. This can be attributed to inflexible labour market in this sector, and the fact that the data used in the estimation are obtained from different sources and have some inconsistencies (it should be noted that manufacturing GDP is a component of the secondary sector GDP). Despite that, the results suggest that it is important for Namibia to increase its GDP up to its potential level in order to reduce unemployment.

As expected, and increase in wages causes unemployment to increase. The coefficients for all the variations of unemployment models are positive and statistically significant. This means that an increase in the cost of labour causes unemployment to increase. This suggests there is a need for wage flexibility. Employees and their trade unions should reduce the effect of their wage demand and help to reduce unemployment.

There is a negative relationship between unemployment and investment. An increase in investment causes unemployment to decrease. The coefficient of investment is statistically significant for all the variations of the estimated unemployment function. Investment must be promoted in order to generate jobs for the majority of the unemployed people.

A test for cointegration revealed that the null hypothesis of no cointegration is rejected and this means that the variables are cointegrated. There is an economic equilibrium relationship between unemployment and the explanatory variables. The ECM results indicate that the dynamics adjust to equilibrium instead of moving away from it. All the results passed diagnostic statistics and the R-squared of more than 50 percent indicates that the model a good fit. Although there are some variables that were not included in the estimated model, future studies should include these variables as the data become more available. 


\section{References}

Bank of Namibia. (1991). Annual Report. Bank of Namibia: Windhoek.

Bank of Namibia. (2004). Annual Report. Bank of Namibia: Windhoek.

Bank of Namibia. (2006). Annual Report. Bank of Namibia: Windhoek.

Bank of Namibia. (2007). Annual Report. Bank of Namibia: Windhoek.

Bhorat, H. (2007). Unemployment in South Africa: Descriptors and Determinants. Paper Presented to the Commission on Growth and Development, World Bank, Washington DC.

Cornwell, R., Leistner, E., \& Esterhuysen, E. (1991). Namibia 1990: An African Institute Country Survey. Pretoria: African Institute of South Africa.

Eita, J.H., \& Du Toit, C.B. (2009). Explaining Long-Term Growth in Namibia. South African Journal of Economic and Management Sciences, 12(1), 48-62.

Fahrer, J., \& Pease, A. (1993). The Unemployment - Vacancy Relationship in Australia. Australian Economic Review, 28, 43-57.

Foley, M.C. (1997). Determinants of Unemployment in Russia, Center Discussion Paper No. 779, Yale University.

Gaomab II, M. (2007). To What Extent do Economic Policies and Structural Heterogeneities Inhibit the Employment Absorptive Capacity of the Namibian Economy? Paper Presented at the NUNW National Symposium on Productivity and Employment, Windhoek.

Hartmann, W.P. (1988). The Role of Mining in the Economy of South West Africa/Namibia 1950-1985, Unpublished Master of Science in Economics Thesis, University of Stellenbosch, Stellenbosch.

Hodrick, R, J., \& Prescott, E.C. (1997). Postwar U.S. Business Cycles: An Empirical Investigation. Journal of Money, Credit and Banking, 29(1), 1-16.

Kingdon, G., \& Knight, J. (2001). Race and the Incidence of Unemployment in South Africa. Centre for the Study of African Economies Working Papers, CSAE WPS/2001-18.

Lippman, S., \& McCall, J. (1976). The Economics of Job Search: A Survey. Economic Inquiry, 14, 155-189.

Ministry of Labour and Social Welfare. (1997). Namibia Labour Force Survey. Windhoek: Directorate of Labour Market Services.

Ministry of Labour and Social Welfare. (2000). Namibia Labour Force Survey. Windhoek: Directorate of Labour Market Services.

Ministry of Labour and Social Welfare. (2004). Namibia Labour Force Survey. Windhoek: Directorate of Labour Market Services.

Monastiriotis, V. (2006). Macro-determinants of UK Regional Unemployment and the Role of Employment Flexibility. EI Working Paper, 01, European Institute.

Mortensen, D. (1970).Job Search, the Duration of Unemployment and the Phillips Curve. American Economic Review, 30, 847-862.

National Planning Commission. (1999). National Accounts: 1980-1998. Windhoek: Central Bureau of Statistics.

National Planning Commission. (2006). National Accounts: 1995-2005. Windhoek: Central Bureau of Statistics.

National Planning Commission. (2008). National Accounts: 2000-2007. Windhoek: Central Bureau of Statistics.

Odada, J.E. (2008). Overview of Structural Transformation of the Namibian Economy. Paper Presented at the $10^{\text {th }}$ Bank of Namibia Annual Symposium, Windhoek.

Rodrick, D. (2006). Understanding South Africa's Economic Puzzles. NBER Working Paper 12565, NBER Working Paper Series.

Schoeman, C., Blaauw, D., and Pretorius, A. (2008). An Investigation into the Determinants of the South African Unemployment Rate, 1970-2002. Acta Academia, 40(3), 67-84.

Valadkhani, A. (2003). The causes of unemployment in Iran: An empirical Investigation. International Journal of Applied Business and Economic Research, 1(1), 21-33. 
Wakeford, J. (2004). Productivity, Wages and Employment in South Africa's Manufacturing Sector, 1970-2002. Development Policy Research Unit Working Paper Series, Working Paper 04/85, Cape Town: University of Cape Town.

\section{Tables}

Table 1. Unemployment in Namibia Compared to other African countries

\begin{tabular}{lll}
\hline Country & Year & Unemployment rate/1 \\
Lesotho & 1999 & 27.3 \\
South Africa & 2006 & 25.5 \\
Namibia & 2004 & 21.9 \\
Botswana & 2006 & 15.3 \\
Tunisia & 2005 & 14.2 \\
Egypt & 2005 & 11.2 \\
Mauritius & 2006 & 9.1 \\
Cameroon & 2001 & 7.5 \\
\hline
\end{tabular}

Source: Namibia Labour Force Surveys, International Labour Organisation and World Bank Development Indicators.

/1 Narrow definition of unemployment (excluding people who are not looking for jobs).

Table 2. Labour Force, Employment and Unemployment, 1991-1993/94-1997-2000-2004 (Strict Definition of Unemployment)

\begin{tabular}{|c|c|c|c|c|c|c|c|c|c|c|c|c|}
\hline \multirow{2}{*}{$\begin{array}{l}\text { SURVEY/A } \\
\text { REA }\end{array}$} & \multicolumn{4}{|c|}{ TOTAL } & \multicolumn{4}{|c|}{ FEMALES } & \multicolumn{4}{|c|}{ MALES } \\
\hline & $\begin{array}{l}\text { Employed } \\
\text { (No.) }\end{array}$ & $\begin{array}{l}\text { Unemp- } \\
\text { loyed } \\
\text { (No.) }\end{array}$ & $\begin{array}{l}\text { Labour } \\
\text { Force } \\
\text { (No.) }\end{array}$ & $\begin{array}{l}\text { Unemp- } \\
\text { loyment } \\
\text { Rate (\%) }\end{array}$ & $\begin{array}{l}\text { Employed } \\
\text { (No.) }\end{array}$ & $\begin{array}{l}\text { Unemp- } \\
\text { loyed (No.) }\end{array}$ & $\begin{array}{l}\text { Labour } \\
\text { Force } \\
\text { (No.) }\end{array}$ & $\begin{array}{l}\text { Unemp- } \\
\text { loyment } \\
\text { Rate (\%) }\end{array}$ & $\begin{array}{l}\text { Employed } \\
(\text { No.) }\end{array}$ & $\begin{array}{l}\text { Unemp- } \\
\text { loyed (No.) }\end{array}$ & \begin{tabular}{|l|} 
Labour \\
Force (No.)
\end{tabular} & $\begin{array}{l}\text { Unemp- } \\
\text { loyment } \\
\text { Rate }(\%)\end{array}$ \\
\hline \multicolumn{13}{|l|}{1991} \\
\hline \multicolumn{13}{|l|}{ NHPS: } \\
\hline Urban & 130232 & 45757 & 175989 & 26 & 47782 & 20478 & 68260 & 30 & 80035 & 25274 & 103309 & 24 \\
\hline Rural & 257782 & 46008 & 303790 & 15 & 123916 & 18515 & 142431 & 13 & 134255 & 27498 & 161753 & 17 \\
\hline National & 388014 & 91765 & 479779 & 19.1 & 171698 & 38993 & 210691 & 19 & 214290 & 52772 & 267062 & 20 \\
\hline \multicolumn{13}{|l|}{ 1993/94 } \\
\hline \multicolumn{13}{|l|}{ NHIES: } \\
\hline Urban & 134407 & 44247 & 178654 & 24.8 & 56001 & 22968 & 78969 & 29 & 78406 & 21279 & 99685 & 21.3 \\
\hline Rural & 215873 & 40151 & 256024 & 15.7 & 107547 & 20784 & 128330 & 16.2 & 108327 & 19367 & 127694 & 15.2 \\
\hline National & 350280 & 84398 & 434678 & 19.4 & 163547 & 43752 & 207299 & 21.1 & 186733 & 40646 & 227379 & 17.9 \\
\hline \multicolumn{13}{|l|}{1997} \\
\hline \multicolumn{13}{|l|}{ NLFS: } \\
\hline Urban & 178033 & 55749 & 233781 & 23.8 & 72209 & 26088 & 98297 & 26.5 & 105824 & 29661 & 135484 & 21.9 \\
\hline Rural & 223170 & 41373 & 264543 & 15.6 & 109546 & 22145 & 131703 & 16.8 & 113624 & 19216 & 132840 & 14.5 \\
\hline National & 401203 & 97121 & 498324 & 19.5 & 181755 & 48245 & 230000 & 21 & 219447 & 48877 & 268324 & 18.2 \\
\hline \multicolumn{13}{|l|}{2000} \\
\hline \multicolumn{13}{|l|}{ NLFS: } \\
\hline Urban & 201985 & 63843 & 265828 & 24 & 91416 & 34099 & 125515 & 27.2 & 110569 & 29745 & 140314 & 21.2 \\
\hline Rural & 229865 & 45755 & 275620 & 16.6 & 113606 & 22145 & 135751 & 16.3 & 116259 & 23610 & 139869 & 16.9 \\
\hline National & 431849 & 109598 & 541447 & 20.2 & 205021 & 56243 & 261264 & 21.5 & 226828 & 53354 & 280182 & 19 \\
\hline \multicolumn{13}{|l|}{2004} \\
\hline \multicolumn{13}{|l|}{ NLFS: } \\
\hline Urban & 219974 & 64904 & 284878 & 22.8 & 98889 & 33494 & 132383 & 25.3 & 121085 & 31410 & 152495 & 20.6 \\
\hline Rural & 165355 & 43215 & 208570 & 20.7 & 69788 & 22631 & 92419 & 24.5 & 95567 & 20585 & 116152 & 17.7 \\
\hline National & 385329 & 108119 & 493448 & 21.9 & 168677 & 56125 & 224882 & 25 & 216652 & 51994 & 268646 & 19.4 \\
\hline
\end{tabular}

Source: Odada (2008: 51); Ministry of Labour and Social Welfare (1997; 2000; 2004).

Note: NPHS is National Population Housing Census Survey.

NHIES is National Housing Income and Expenditure Survey.

NLFS is Namibia Labour Force Survey. 
Table 3. Labour Force, Employment and Unemployment, 1993/94 and 1997 (Broad Definition of Unemployment)

\begin{tabular}{|c|c|c|c|c|c|c|c|c|c|c|c|c|}
\hline \multirow{2}{*}{$\begin{array}{l}\text { SURVEY/ } \\
\text { AREA }\end{array}$} & \multicolumn{4}{|c|}{ TO TAL } & \multicolumn{4}{|c|}{ FEMALES } & \multicolumn{4}{|c|}{ MALES } \\
\hline & $\begin{array}{l}\text { Employed } \\
\text { (No.) }\end{array}$ & $\begin{array}{l}\text { Unemp- } \\
\text { loyed } \\
\text { (No.) }\end{array}$ & $\begin{array}{l}\text { Labour } \\
\text { Force } \\
\text { (No.) }\end{array}$ & $\begin{array}{l}\text { Unemp- } \\
\text { loyment } \\
\text { Rate (\%) }\end{array}$ & $\begin{array}{l}\text { Employe } \\
\text { d (No.) }\end{array}$ & $\begin{array}{l}\text { Unemp- } \\
\text { loyed } \\
\text { (No.) }\end{array}$ & \begin{tabular}{|l} 
Labour \\
Force \\
(No.).
\end{tabular} & $\begin{array}{l}\text { Unemp- } \\
\text { loyment } \\
\text { Rate (\%) }\end{array}$ & $\begin{array}{l}\text { Employe } \\
\text { d (No.) }\end{array}$ & $\begin{array}{l}\text { Unemp- } \\
\text { loyed } \\
\text { (No.) }\end{array}$ & $\begin{array}{l}\text { Labour } \\
\text { Force } \\
\text { (No.). }\end{array}$ & $\begin{array}{l}\text { Unemp- } \\
\text { loymen } \\
\text { t Rate } \\
(\%)\end{array}$ \\
\hline \multicolumn{13}{|l|}{ 1993/94 } \\
\hline \multicolumn{13}{|l|}{ NHIES: } \\
\hline Urban & 134407 & 62124 & 196531 & 31.6 & 56001 & 37087 & 93088 & 39.8 & 78406 & 25037 & 103443 & 24.2 \\
\hline Rural & 215873 & 109417 & 325290 & 33.6 & 107547 & 68812 & 176358 & 39 & 108327 & 40605 & 148932 & 27.3 \\
\hline National & 350280 & 171541 & 521821 & 32.9 & \begin{tabular}{|l|l|}
163 & 547
\end{tabular} & 105899 & 269446 & 39.3 & 186733 & 65642 & 252375 & 26 \\
\hline \multicolumn{13}{|l|}{1997} \\
\hline \multicolumn{13}{|l|}{ NLFS: } \\
\hline Urban & 178033 & 85472 & 263504 & 32.4 & 72209 & 46792 & 119001 & 39.3 & 105824 & 36680 & 144503 & 26.8 \\
\hline Rural & 223170 & 125944 & 349114 & 36.1 & 109546 & 76618 & 186165 & 41.2 & 113624 & 49326 & 162950 & 30.3 \\
\hline National & 401203 & 211416 & 612618 & 34.5 & 181755 & 123410 & 305165 & 40.4 & 219447 & 88006 & 307453 & 28.6 \\
\hline \multicolumn{13}{|l|}{2000} \\
\hline \multicolumn{13}{|l|}{ NLFS: } \\
\hline Urban & 201985 & 91934 & 293919 & 31.3 & 91416 & 54213 & 145629 & 37.2 & 110569 & 37721 & 148290 & 25.4 \\
\hline Rural & 229865 & 128700 & 358565 & 35.9 & 113606 & 77071 & 190677 & 40.4 & 116529 & 51629 & 167888 & 30.8 \\
\hline National & 431850 & 220634 & 652484 & 33.8 & \begin{tabular}{|l|}
205021 \\
\end{tabular} & 131284 & 336305 & 39 & 226828 & 89350 & 316178 & 28.3 \\
\hline \multicolumn{13}{|l|}{2004} \\
\hline \multicolumn{13}{|l|}{ NLFS: } \\
\hline Urban & 219974 & 89726 & 309700 & 29 & 98889 & 50549 & 149438 & 33.8 & 121085 & 39177 & 160262 & 24.4 \\
\hline Rural & 165355 & 133554 & 298909 & 44.7 & 69788 & 78623 & 148711 & 53 & 95567 & 54932 & 150499 & 36.5 \\
\hline National & 385329 & 223281 & 608610 & 36.7 & 168677 & 129172 & \begin{tabular}{|l|l|}
298149 \\
\end{tabular} & 43.4 & 216652 & 94109 & 310761 & 30.3 \\
\hline
\end{tabular}

Source: Ministry of Labour and Social Welfare (1997; 2000; 2004) and Odada (2008: 52).

Note: NHIES is National Housing Income and Expenditure Survey.

NLFS is Namibia Labour Force Survey. 
Table 4. ADF unit root test

\begin{tabular}{|c|c|c|c|}
\hline Variable & Model specification & Test in levels & Test in first differences \\
\hline $\ln U_{t}$ & $\begin{array}{l}\text { Constant and trend } \\
\text { Constant } \\
\text { None }\end{array}$ & $\begin{array}{l}-0.717 \\
-2.781 \\
3.595\end{array}$ & $\begin{array}{l}-5.201 * * * \\
-4.473 * * * \\
-3.654 * * *\end{array}$ \\
\hline $\ln P_{t}$ & $\begin{array}{l}\text { Constant and trend } \\
\text { Constant } \\
\text { None }\end{array}$ & $\begin{array}{l}2.692 \\
-2.383 \\
-0.655\end{array}$ & $\begin{array}{l}-2.774 \\
-1.859 \\
-0.606 \\
\end{array}$ \\
\hline$\left[\ln Y_{t}^{a}-Y_{t}^{p}\right] \#$ & $\begin{array}{l}\text { Constant and trend } \\
\text { Constant } \\
\text { None }\end{array}$ & $\begin{array}{l}-4.068 * * \\
1.509 \\
2.361\end{array}$ & $\begin{array}{l}-2.026 \\
-2.674^{*} \\
0.256\end{array}$ \\
\hline$\left[\ln Y_{t}^{a}-Y_{t}^{p}\right] \# \#$ & $\begin{array}{l}\text { Constant and trend } \\
\text { Constant } \\
\text { None }\end{array}$ & $\begin{array}{l}-3.815^{* *} \\
-4.143^{* * *} \\
2.784\end{array}$ & $\begin{array}{l}4.525 * * * \\
-3.703 * * * \\
-0.982\end{array}$ \\
\hline$\left[\ln Y_{t}^{a}-Y_{t}^{p}\right] \# \# \#$ & $\begin{array}{l}\text { Constant and trend } \\
\text { Constant } \\
\text { None }\end{array}$ & $\begin{array}{l}-3.489 * * \\
-3.534 * * \\
-0.322 \\
\end{array}$ & $\begin{array}{l}-6.182 * * * \\
-6.273 * * * \\
-6.365 * * * \\
\end{array}$ \\
\hline $\ln R W_{t}$ & $\begin{array}{l}\text { Constant and trend } \\
\text { Constant } \\
\text { None }\end{array}$ & $\begin{array}{l}-2.541 \\
0.313 \\
4.553 \\
\end{array}$ & $\begin{array}{l}-4.386 * * * \\
-4.411 * * * \\
-3.003 * * * \\
\end{array}$ \\
\hline $\ln I_{t}$ & $\begin{array}{l}\text { Constant and trend } \\
\text { Constant } \\
\text { None }\end{array}$ & $\begin{array}{l}-1.397 \\
-0.878 \\
1.107 \\
\end{array}$ & $\begin{array}{l}-6.380 * * * \\
-6.259 * * * \\
-6.178 * * * \\
\end{array}$ \\
\hline $\ln P R O D_{t}$ & $\begin{array}{l}\text { Constant and trend } \\
\text { Constant } \\
\text { None }\end{array}$ & $\begin{array}{l}-2.798 \\
-1.386 \\
-1.721 * \\
\end{array}$ & $\begin{array}{l}-5.863 * * * \\
-5.906 * * * \\
-5.468 * * * \\
\end{array}$ \\
\hline
\end{tabular}

Notes: \# GDP gap computed using the total GDP.

\#\# GDP gap computed using GDP of the secondary sector.

\#\#\# GDP gap computed using manufacturing GDP.

$* / * * / * * *$ Indicates rejection of the null hypothesis of unit root at $10 \% / 5 \% / 1 \%$ significance level.

Table 5. Long-run regression results

\begin{tabular}{|l|l|l|l|}
\hline & \multicolumn{3}{|c|}{ Dependent variable } \\
\hline Explanatory variables & \multicolumn{1}{|c|}{$\ln U_{t}$} & \multicolumn{1}{|c|}{$\ln U_{t}$} & \multicolumn{1}{|c|}{$\ln U_{t}$} \\
\hline $\ln P_{t}$ & $-0.074(-0.0759)$ & $-0.231(-1.938)^{*}$ & $-0.211(0.643)$ \\
\hline$\left[\ln Y_{t}^{a}-Y_{t}^{p}\right] \#$ & $1.300(2.464)^{* *}$ & & \\
\hline$\left[\ln Y_{t}^{a}-Y_{t}^{p}\right] \# \#$ & & $0.833(1.977)^{*}$ & \\
\hline$\left[\ln Y_{t}^{a}-Y_{t}^{p}\right] \# \# \#$ & & & $0.119(0.175)$ \\
\hline $\ln R W_{t}$ & $0.881(2.011)^{*}$ & $1.789(3.817)^{* * *}$ & $1.573(3.231)^{* * *}$ \\
\hline $\ln I_{t}$ & $-0.438(-5.420)^{* * *}$ & $-0.231(-1.938)^{*}$ & $-0.372(-3.629)^{* * *}$ \\
\hline $\ln P R O D_{t}$ & $0.426(1.579)$ & & \\
\hline Time trend & & $0.064(1.585)$ & $0.042(1.008)$ \\
\hline Constant & $-3.160(-0881)$ & $-3.162(0.676)$ & $0.655(0.886)$ \\
\hline Adjusted R-Squared & 0.97 & 0.96 & 0.96 \\
\hline
\end{tabular}

Notes: \# GDP gap computed using the total GDP.

\#\# GDP gap computed using GDP of the secondary sector.

\#\#\# GDP gap computed using manufacturing GDP.

$* / * * / * * *$ statistically significant at $10 \% / 5 \% / 1 \%$ significance level.

t-statistics are in brackets. 
Table 6. Error correction model results

\begin{tabular}{|c|c|c|c|}
\hline \multirow[t]{2}{*}{ Explanatory Variables } & \multicolumn{3}{|c|}{ Dependent Variable } \\
\hline & $\sin U_{t} \#$ & $\Delta \operatorname{Ln} U_{t} \# \#$ & $\Delta \ln U_{t} \# \#$ \\
\hline $\operatorname{ECM}(-1)$ & $-0.352(-2.347)^{* *}$ & $-0.496(-3.828)^{* * *}$ & $-0.478(-4.093)^{* * *}$ \\
\hline$\Delta \ln \left[Y^{a}-Y^{b}\right]_{t}$ & $3.728(1.957)^{*}$ & & \\
\hline$\Delta \ln \left[Y^{a}-Y^{b}\right]_{t-1}$ & & $8.239(4.187)^{* * *}$ & \\
\hline$\Delta \ln \left[Y^{a}-Y^{b}\right]_{t-2}$ & & $-7.747(-4.037)^{* * *}$ & \\
\hline$\Delta \ln \left[Y^{a}-Y^{b}\right]_{t-3}$ & & & $-0.730(-2.006)^{*}$ \\
\hline$\Delta \ln I_{t}$ & $-0.221(-3.538)^{* * *}$ & & $-0.203(-3.397)^{* * *}$ \\
\hline$\Delta \ln I_{t-1}$ & & & $-0.165(-2.753)^{* *}$ \\
\hline$\Delta \ln P_{t-2}$ & $1.208(2.055)^{* *}$ & & \\
\hline$\Delta \ln P_{t-3}$ & $1.550(2.527)^{* *}$ & $1.165(2.300)^{* * *}$ & \\
\hline$\Delta \ln R W_{t-1}$ & & & $-0.480(1.468)$ \\
\hline$\Delta \ln U N C E R_{t-3}$ & $-0.175(-2.140)^{* *}$ & & $-0.236(-2.818)^{* *}$ \\
\hline DUMIND & & & $-0.055(-2.532)^{* *}$ \\
\hline Time trend & & $-0.002(-2.202)^{* *}$ & \\
\hline Constant & $-0.352(-2.347)^{* *}$ & $-0.033(-0.573)$ & $0.110(5.748)^{* * *}$ \\
\hline R-squared & 0.577 & 0.555 & 0.63 \\
\hline
\end{tabular}

Notes: \# GDP gap computed using the total GDP (ECM of column 2 in Table 5).

\#\# GDP gap computed using GDP of the secondary sector (ECM of column 3 in Table 5).

\#\#\# GDP gap computed using manufacturing GDP (ECM of column 4 in Table 5).

$* / * * / * * *$ statistically significant at $10 \% / 5 \% / 1 \%$ significance level.

t-statistics are in brackets. 